\title{
Evaluation of Hormones and Trace Elements in Women with Unexplained Infertility
}

\author{
Khansaa. A. Hussien , ${ }^{* P r o f . ~ D r . ~ R a i d ~ M . ~ H . ~ A l-S a l i h ~}{ }^{1}$ and Prof. Dr. Saher. A. Ali \\ ${ }^{1}$ Chemistry Dept. / College of Science / Thi-Qar University
}

\section{Summary}

This study aims to Evaluation of prolactin (PRL), thyroid stimulating hormone (TSH), luteinizing (LH)and Follicle stimulating hormone(FSH)and trace elements (iron and copper) in women with unexplained infertility (UI). 60 women with unexplained infertility as well as (40) women with polycystic ovarian syndrome (PCOS) aged (2035) year were included in this study. The women were divided according the type of infertility into primary and secondary groups ( $1^{\circ} \mathrm{UI}, 2^{\circ} \mathrm{UI}, 1^{\circ} \mathrm{PCO}$ and $\left.2^{\circ} \mathrm{PCO}\right)$ respectively. Fifty healthy fertile women with the same age were included in this study as a control group. The results showed a significant increase in serum of Prolactin, TSH, LH levels in the two groups of women with explained infertility (pcos) compared to control and the two groups of women with unexplained infertility. In contrast no significant differences in Prolactin, TSH, FSH and LH levels in women with unexplained infertility in comparison with the control.Serum levels of iron and copper significantly increase in unexplained infertility groups in comparison with women with explained infertility and control groups. This study concluded that is Prolactin, TSH and LH hormone are not associated statistically with unexplained female infertility. The increase in $\mathrm{Cu}$ and iron may have an important etiological role in the pathogenicity of unexplained infertility.

Keywords: Unexplained infertility, PCOS, Hormone, Trace elements, Iron, Copper 


\section{Introduction}

Infertility is defined as the inability to conceive naturally after one year of regular unprotected intercourse. Most of the time, infertility is some degree of subfertility in which 1 in 7 couples need specialist help to conceive. Subfertility can be either primary or secondary. ${ }^{1}$ Infertility of unknown origin comprises both idiopathic and unexplained infertility. ${ }^{(2,3)}$ Most of the infertile couples have one of these three major causes including a male factor, ovulatory dysfunction, or tubal-peritoneal disease. ${ }^{(4)}$ According to the Center of Disease Control (CDC, 2013), ${ }^{(5)}$ the causes of female infertility can be divided into three broad categories including defective ovulation, transport and implantation. ${ }^{(6)}$ Unexplained infertility is one of the controversial subjects in infertility on which agreement is rarely found among practitioners. It is a term used to define $30-40 \%$ of couples in whom standard investigations including semen analysis, tests of ovulation and tubal patency have failed to detect any gross abnormality. ${ }^{(3)}$ Couples with unexplained infertility suffer from both diminished and delayed fecundity. ${ }^{(7)}$

The diagnosis of unexplained infertility may be frustrating because if there is no explanation for infertility, there is no effective treatment. ${ }^{(7)}$ The prognosis is worse if the duration of infertility exceeds 3 years and female partner is > 35 years of age. (8) Treatment has been indicated if the duration is more than 2 years or the female partner is $>35$ years of age. ${ }^{(8,9)}$ Polycystic ovary syndrome (PCOS) is characterized by hyperandrogenism, chronic anovulation and polycystic ovaries. $(10,11)$ The prevalence of classical forms of PCOS is from 6-9 to $19.9 \%$ and is even higher in women with menstrual disorders (17.4-46.4\%), hyperandrogenism (72.1-82.0\%), and anovulatory infertility $(55-91 \%){ }^{(12,13)}$ Clinical symptoms include ovulatory dysfunction, hyperandrogenism, and polycystic ovaries. Metabolic disorders (obesity, insulin resistance, impaired glucose tolerance, type II diabetes mellitus, and dyslipidemia) are typical of $40-85 \%$ women with PCOS. ${ }^{(14)}$

Hormones from pituitary gland like $\mathrm{TSH}$, prolactin or growth hormone may act synergistically with FSH and 
LH to enhance the entry of nongrowing follicles into growth phase. In addition to this, thyroid hormones may be necessary for maximum production of both estradiol and progesterone. ${ }^{(15)}$

It is well known that the function of the thyroid hormones includes modulation of carbohydrates, proteins and fat metabolism, gene expression and also sexual and reproductive function and when the thyroid hormone gets out of balance, many body functions are affected. (16) Thyroid dysfunction in females have been found to be associated with anovulatory cycles, decreased fecundity and increased morbidity during pregnancy. ${ }^{(17)}$

Hyperprolactinemia also adversely affects the fertility potential by impairing the pulsatile secretion of GnRH and hence interfering with ovulation. ${ }^{(18)}$ Moreover it is associated with menstrual as well as ovulatory dysfunctions like amenorrohea, oligomenorrhoea, anovulation, inadequate corpus leuteal phase and galactorrhoea. ${ }^{(19)}$

Hyperprolactinaemia results in inhibition of gonadotrophin releasing hormone $(\mathrm{GnRH})$ release pulsatility from the hypothalamus and subsequent inhibition of LH and follicle stimulating hormone, ${ }^{(20,21)}$ leading to inhibition of ovarian function. Chronic increases in $17 \mathrm{~b}$-estradiol also stimulate prolactin secretion, both through actions on the pituitary gland and through hypothalamic mechanisms. (22) High levels of circulating PRL, in physiology and pathological situations, are known to cause infertility. ${ }^{(21)}$

Hypothyroidism can affect fertility due to anovulatory cycles, luteal phase defects, hyperprolactinemia and sex hormone imbalance. ${ }^{(17)}$ Thyroid dysfunction is a condition known to reduce the likely hood of pregnancy and to adversely affect pregnancy outcome.

Abnormal patterns of gonadotropin secretion, including increased serum luteinizing hormone (LH) concentrations, low-normal follicle-stimulating hormone (FSH) levels, and increased LH/FSH ratios have long been recognized as common characteristics of women with PCOS. (23)

Trace elements play a vital role in many different biological functions. The relationship of trace elements to different disease states has long been known. (24) Although trace elements 
are essential components of biological structures or essential for enzymatic function, they can be toxic at higher concentrations beyond what is necessary for their biological functions. ${ }^{(25)}$ Nutritional elements such as $\mathrm{Zn}, \mathrm{Cu}$, and $\mathrm{Se}$ are components of proteins, enzymes and hormones, which regulate many processes, including balancing redox reactions, immune response, and formation of connective tissue during development. ${ }^{(26)}$

Iron is an element essential for life and maintaining normal organism function. It is also necessary for the production of myoglobin, oxidative phosphorylation within mitochondria, DNA synthesis. ${ }^{(27)}$ Copper is normally bound to proteins as an essential enzymatic component. In terms of storage capacity, high concentrations of $\mathrm{Cu}$ are found in liver, which is the central organ for $\mathrm{Cu}$ homeostasis. ${ }^{(28)}$ Other organs that have high concentrations of $\mathrm{Cu}$ are the brain, heart, stomach and intestine. Free $\mathrm{Cu}^{+}$ is a potent oxidant causing the generation of ROS in cells. Thus, the tight regulation of $\mathrm{Cu}$ homeostasis is required to maintain $\mathrm{Cu}$ uptake, transport, storage, and excretion activities. $^{(29)}$

\section{Patients and Method}

This study has been conducted at AL-Hussein Teaching Hospital in ThiQar, Biochemistry Laboratory in College of Science, at the period between 10/8/2016 to $25 / 5 / 2017$. Informed consent was obtained verbally from all participants. A total of one hundred women with infertility of the ages $20-35$ years. The women are already diagnosed as infertile women by the consultant medical staff, according to clinical examination and symptoms. To compare the results, fifty healthy age matched females with a history of at least one child birth were also enrolled. The present study included (150) females, which divided into two general groups:

1. Control group: included (50) apparently healthy Fertile women.

2. Case group: included (100) infertile women

Table(1).Details of numbers and age of the studied groups

\begin{tabular}{|c|c|c|}
\hline Groups & No. & Rang of Age (year) \\
\hline Patients (infertile women) & 100 & $20-35$ \\
\hline
\end{tabular}




\section{Control ( fertile women)} Total

\section{0}

150
20-35

20-35

Also the women in this study were divided into subgroups according to type of infertility of infertile women showed as followings:

1- (1ºI): included (30) woman with primary unexplained infertile women.

2- (2 UI): included (30) woman with secondary unexplained infertile women.

3- ( $\left.{ }^{\circ} \mathrm{PCO}\right)$ : included (20) woman with primary explained infertile women (PCOS).

4- ( $\left.2^{\circ} \mathrm{PCO}\right)$ : included(20) woman with secondary explained infertile women (PCOS).

\section{Specimen collection}

About $(5 \mathrm{~mL})$ of blood samples was collected by vein puncture using a sterile disposable syringe in plain plastic tubes. The serum was separated immediately in order to allow clotting at room temperature. The blood was centrifuged at 3000 revolution per minute $(\mathrm{rpm})$ for 10 minutes and stored in plain tubes at $\left(-20^{\circ} \mathrm{C}\right)$ until used or immediately analysed.

\section{Determination of Serum Hormones}

The Hormones (PRL, TSH, FSH, and LH) are a Full automated quantitative test for use with Autoanalyzer Cobas e411 instruments were used for the determination of (PRL TSH, FSH, and LH) in human serum or plasma using Elecsys and Cobas e immunoassay analyzers.

\section{Determination of Serum Trace Element Concentration}

Serum iron concentration was measured according to the method of iron kit. The used reagents were supplied by (Randox, UK).Serum $\mathrm{Cu}$ concentration was measured according to the method of copper kit (Spectrum, Germany).

\section{Statistical Analysis}

The Statistical Analysis System- SAS (2012) program was used to effect of difference factors in study parameters. Least significant difference - LSD test was used to significant compare between means in this study. 


\section{Result and Discussion}

The women with primary and secondary unexplained infertility (UI) had the mean age of $29.25 \pm 6.26$ and $33.69 \pm 6.36$ years respectively, and the mean age of women with primary and secondary explained infertility (PCOS) groups were $25.844 \pm 4.47$ and $28.44 \pm 4.21$ years respectively. The mean age of the control group was $32.28 \pm 6.70$ years. The women with primary and secondary (UI) had the mean BMI values of $26.44 \pm 3.24$ and $27.27 \pm 4.04 \mathrm{~kg} / \mathrm{m}^{2}$ respectively, and the mean BMI values of women with primary and secondary (PCOS) were $30.77 \pm 3.11$ and $31.34 \pm 4.12 \mathrm{~kg} / \mathrm{m}^{2}$, respectively. The mean BMI value of control group was $64.02 \pm 6.96 \mathrm{~kg} / \mathrm{m}^{2}$.

\section{Serum Hormones Concentration}

Table (2) shows no significant differences in Prolactin, TSH, FSH and LH levels in the two groups of women with $\left(1^{\circ} \mathrm{UI}\right)$ and $\left(2^{\circ} \mathrm{UI}\right)$ in comparison with the control group. These results are in agreement with Beyazit et al. 2016 and Verit et al., 2017. ${ }^{(30,31)}$ Also the study found no significant differences in such hormones levels between the two groups of the women with UI, can be observed.

The same table shows a significant increase in Prolactin, TSH and LH hormone levels in the two groups of women with explained infertility $\left(1^{\circ} \mathrm{PCO}\right)$ and $\left(2^{\circ} \mathrm{PCO}\right)$ in comparison with the control group ( $\mathrm{p} \leq 0.05$ ). These results agree with the results reported by George and Malini 2014 ; Shah et al. 2017. ${ }^{(32,33)}$ The current study shows a significant increase in Prolactin, TSH and LH hormone levels in the two groups of women with (PCOS) in comparison with the two groups of women with (UI) respectively $(\mathrm{p} \leq 0.05)$. This result agrees with the study of Diamond et al. 2017, ${ }^{(34)}$ while there are no significantly differences in Prolactin, TSH and LH hormone levels between the two groups of the women with explained infertility (PCOS).These results are matched with the results of the study of Spandana et al. 2017. ${ }^{(35)}$

However the results showed no significant differences in FSH hormone levels in the two groups of the women with PCO in comparison with the control group. it is no 
significant differences in FSH hormone levels between the two groups of the women with explained infertility ( $\left.1^{\circ} \mathrm{PCO}\right)$ and $\left(2^{\circ} \mathrm{PCO}\right)$ in comparison with the two groups of the women with unexplained infertility $\left(1^{\circ} \mathrm{UI}\right)$ and $\left(2^{\circ} \mathrm{UI}\right)$ respectively. These results agree with the two studies of Beyazit et al. 2016 and Mohammed et al. 2016. ${ }^{(30,36)}$ Also, no significant differences in FSH hormone levels between the two groups of women with (PCOS) can be observed.

The high prolactin, TSH and LH levels were found in PCOS women in the present study. Hyperprolactinemia can cause symptoms similar to PCOS. Reports have suggested that women with PCOS have elevated prolactin levels. This increased prolactin may augment by the inhibition of 3beta-hydroxysteroid dehydrogenase activity or, less often, through selective action on the sulfation of DHEA in adrenal or extra-adrenal sites. ${ }^{(32)}$

In many infertility cases, the diagnosis is simply unexplained because a variety of reasons like lack of ovulation, mechanical stoppage and parental age etc. ${ }^{(37)}$ hypothyroidism is defined by high TSH and normal thyroid hormones. ${ }^{(38,39)}$ Hypothyroidism is one of the causes of ovulation dysfunction in women, resulting in infertility. ${ }^{(40)}$ The ovulation can be affected by hormonal imbalance, thyroid disorders or chronic diseases such as diabetes. ${ }^{(41)}$ Some women with hyperprolactinemia might have primary hypothyroidism.

Abnormality of the hypothalamic-pituitary ovarian or adrenal axis has been implicated in PCOS. Disturbance in the pulsatility of gonadotrophin releasing hormone $(\mathrm{GnRH})$ results in the relative increase in LH to FSH release. An abnormal feedback mechanism by ovarian estrogen is blamed to play role in this discriminated increase in $\mathrm{LH}$ release. ${ }^{(42,35)}$

\begin{tabular}{|l|l|l|l|l|l|}
\hline Groups & NO. & $\begin{array}{l}\text { PRL } \\
(\mu \mathbf{U} / \mathbf{m l})\end{array}$ & $\begin{array}{l}\text { TSH } \\
(\boldsymbol{\mu U} / \mathbf{m l})\end{array}$ & LH $(\boldsymbol{\mu U} / \mathbf{m l})$ & FSH( $\boldsymbol{\mu U} / \mathbf{m l})$ \\
\hline Control & 50 & $14.5 \pm 3.9^{\mathrm{b}}$ & $2.3 \pm 0.7^{\mathrm{b}}$ & $3.2 \pm 0.9^{\mathrm{bc}}$ & $5.4 \pm 1.4^{\mathrm{a}}$ \\
\hline $\mathbf{1}^{\mathbf{o}} \mathbf{U I}$ & 30 & $14.5 \pm 2.9^{\mathrm{b}}$ & $2.3 \pm 0.7^{\mathrm{b}}$ & $2.6 \pm 0.7^{\mathrm{c}}$ & $5.3 \pm 1.2^{\mathrm{a}}$ \\
\hline $\mathbf{2}^{\mathbf{o}} \mathbf{U I}$ & 30 & $14.4 \pm 2.9^{\mathrm{b}}$ & $2.1 \pm 0.6^{\mathrm{b}}$ & $3.6 \pm 1.0^{\mathrm{b}}$ & $5.4 \pm 1.4^{\mathrm{a}}$ \\
\hline
\end{tabular}




\begin{tabular}{|l|l|l|l|l|l|}
\hline $\mathbf{1}^{\mathbf{o}}(\mathbf{P C O})$ & 20 & $16.3 \pm 3.0^{\mathrm{a}}$ & $2.8 \pm 0.7^{\mathrm{a}}$ & $8.1 \pm 1.8^{\mathrm{a}}$ & $5.3 \pm 1.3^{\mathrm{a}}$ \\
\hline $\mathbf{2}^{\mathbf{o}}$ (PCO) & 20 & $16.1 \pm 3.0^{\mathrm{a}}$ & $2.9 \pm 0.8^{\mathrm{a}}$ & $8.0 \pm 1.7^{\mathrm{a}}$ & $5.4 \pm 1.4^{\mathrm{a}}$ \\
\hline
\end{tabular}

Table (2):-Serum Hormones levels of control and infertile groups

-Each value represents mean \pm S.D values with non-identical superscript $(a, b$ or $c$ ...etc.) were considered significantly differences $(P \leq 0.05)$. Control: fertile woman, $\mathbf{1}^{\mathbf{0}} \mathbf{U I}$ : Primary unexplained infertility, $\mathbf{2}^{\mathbf{}} \mathbf{U I}$ : Secondary unexplained infertility, $\mathbf{1}^{\mathbf{0}} \mathbf{P C O}$ : Primary explained infertility, $\mathbf{2}^{\mathbf{0}} \mathbf{P C O}$ : Secondary explained infertility, No: Number of subjects, SD: Standard deviation, LSD:Least Significant Difference.

\section{Serum Trace Elements Concentration}

Table (3) shows a significant increase in the concentration of serum Fe in the two groups of the women with unexplained infertility $\left(1^{\circ} \mathrm{UI}\right)$ and $\left(2^{\circ} \mathrm{UI}\right)$ in comparison with control group $(\mathrm{p} \leq 0.05)$. Also, it is found a significant increase in the concentration of serum $\mathrm{Fe}$ in $\left(1^{\circ} \mathrm{UI}\right)$ in comparison with $\left(2^{\circ} \mathrm{UI}\right)$, ( $\left.1^{\circ} \mathrm{PCOS}\right)$ and $\left(2^{\circ} \mathrm{PCO}\right)$ groups respectively $(\mathrm{p} \leq 0.05)$, but there are no significant differences in the concentration of serum $\mathrm{Fe}$ between $\left(2^{\circ} \mathrm{UI}\right),\left(1^{\circ} \mathrm{PCOS}\right)$ and $\left(2^{\circ} \mathrm{PCO}\right)$ groups respectively $(\mathrm{p} \leq 0.05)$. The same Table shows no significant differences in the concentration of serum $\mathrm{Fe}$ in the two groups of women with explained infertility $\left(1^{\circ} \mathrm{PCOS}\right)$ and $\left(2^{\circ} \mathrm{PCO}\right)$ in comparison with control group $(\mathrm{p} \leq 0.05)$.

Table (3) shows a significant increase in the concentration of serum $\mathrm{Cu}$ in the two groups of the women with unexplained infertility $\left(1^{\circ} \mathrm{UI}\right)$ and $\left(2^{\circ} \mathrm{UI}\right)$ in comparison with control group $(p \leq 0.05)$. Also it is a significant increase in the concentration of serum $\mathrm{Cu}$ in the two groups of women with unexplained infertility $\left(1^{\circ} \mathrm{UI}\right)$ and $\left(2^{\circ} \mathrm{UI}\right)$ in comparison withtwo groups of the women with explained infertility $\left(1^{\circ} \mathrm{PCO}\right)$ and $\left(2^{\circ} \mathrm{PCO}\right)$ respectively $(\mathrm{p} \leq 0.05)$. While there are no significant differences in the concentration of serum $\mathrm{Cu}$ between the two groups of women with unexplained infertility $(\mathrm{p} \leq 0.05)$.

The same Table shows a significant increase in the concentration of serum $\mathrm{Cu}$ in two groups of the women with explained infertility $\left(1^{\circ} \mathrm{PCO}\right)$ and $\left(2^{\circ} \mathrm{PCO}\right)$ groups in 
comparison with control group $(\mathrm{p} \leq 0.05)$. But no significant differences in the concentration of serum $\mathrm{Cu}\left(1^{\circ} \mathrm{PCO}\right)$ and $\left(2^{\circ} \mathrm{PCO}\right)$ groups $(\mathrm{p} \leq 0.05)$, can be observed. This study shows a significant increase in the concentration of serum Fe in two groups of women with unexplained infertility $\left(1^{\circ} U I\right)$ and $\left(2^{\circ} U I\right)$ in comparison with fertile women. Also, there are a significant increase in the levels of serum Fe in $\left(1^{\circ} \mathrm{UI}\right)$ in comparison $\left(2^{\circ} \mathrm{UI}\right),\left(1^{\circ} \mathrm{PCOS}\right)$ and $\left(2^{\circ} \mathrm{PCO}\right)$ groups respectively $(\mathrm{p} \leq 0.05)$. This result disagreement with the study of Alwais et al. 2016. ${ }^{(43)}$

There are no significant differences in the concentration of serum Fe between $\left(2^{\circ} \mathrm{UI}\right),\left(1^{\circ} \mathrm{PCOS}\right)$ and $\left(2^{\circ} \mathrm{PCO}\right)$ in comparison with fertile women. This result matched with the results study of Alwais et al. 2016. ${ }^{(43)}$ The non-significant differences in the concentration of serum iron between two groups of women with explained infertility $\left(1^{\circ} \mathrm{PCOS}\right)$ and $\left(2^{\circ} \mathrm{PCO}\right)$ in comparison with fertile women. This result matched with the results study of Li et al., 2016. ${ }^{(44,45)}$

In this study it is found high concentration of serum iron in women with unexplained infertility. There are few studies investigated the effect of iron overload (toxicity) and fertility and even less with regard to female fertility. However, there is a link between iron overload and female infertility.(46) Excess iron leads to reduced production of the hormones LH and FSH from the anterior pituitary suggesting impaired oocyte maturation and low ovarian reserve. ${ }^{(47)}$ In this study, no significant differences in serum levels of iron and were observed between the two groups of the women with (PCOS) and control group. A research conducted by Taghavi et al. in 2009 in Iran on 50 PCOS patients without overweight did not show iron overload in these patients. ${ }^{(48)}$ A cross-sectional study of Lim et al. on 578 people in 2016 indicated that the serum levels of iron had no difference between the two PCOS and non-PCOS groups. ${ }^{(44)}$

In this study the high concentration of serum $\mathrm{Cu}$ in the women with unexplained infertility reported by the current study matched with the results of study of AL-Saraf et al., 2005, ${ }^{(49)}$ but disagreement with results of study of Bawa and Tyagi who suggest the copper lower in the women with primary and secondary unexplained infertility than in control subjects and suggest that hypocupraemia may be a factor in the aetiology of infertility in these women. ${ }^{(50)}$ Whereas the reported significant increase in 
the concentration of serum $\mathrm{Cu}$ in two groups of women with explained infertility in comparison with fertile women, matched with the results of studies of Kurdoglu et al., 2012 and Muyan, 2016. ${ }^{(51,52)}$ but disagreement with the results of study of Bawa and Tyagi who suggest the copper lower in the women with primary and secondary explained infertility than in control subjects. ${ }^{(50)}$ The elevation in serum copper levels may directly affect infertility rates by lowering progesterone levels resulting in annovulation, implantation failure or luteal phase deficits. ${ }^{(53)}$ Copper has also been shown to block the absorption of many essential minerals directly involved with reproductive pathways, especially zinc. ${ }^{(54)}$

In this work there were high levels of serum $\mathrm{Cu}$ concentration in women with (PCOS) in comparison with fertile women. The PCOS patients also had a statistically and significantly higher amount of copper than the control group. ${ }^{(52)}$ The survey conducted by Celik on copper, homocysteine, and early vascular disease in lean women with PCOS showed high copper levels in PCOS patients. ${ }^{(55)}$ A similar result was obtained by a study on mice. ${ }^{(56)}$ Previous studies have shown that patients with PCOS Copper is involved in the metabolism of oxygen and plays an important role in free radical reactions. ${ }^{(57,52,58)}$

Table (3):-Serum trace elements levels of control and infertile groups

\begin{tabular}{|c|c|c|c|}
\hline Groups & NO. & $\begin{array}{c}\mathrm{Fe}(m g / d l) \\
m e a n \pm S D\end{array}$ & $\begin{array}{c}\mathrm{Cu}(\mathrm{mg} / \mathrm{dl}) \\
\mathrm{mean} \pm \mathrm{SD}\end{array}$ \\
\hline Control & 50 & $82.55 \pm 15.79^{c}$ & $105.11 \pm 21.38^{c}$ \\
\hline $1^{\circ} \mathrm{UI}$ & 30 & $125.01 \pm 24.28^{a}$ & $188.06 \pm 56.40^{\mathrm{a}}$ \\
\hline $2^{\circ} \mathrm{UI}$ & 30 & $114.69 \pm 26.36^{b}$ & $175.24 \pm 43.00^{\mathrm{a}}$ \\
\hline $1^{\circ}$ PCO & 20 & $84.03 \pm 5.65$ & $121.41 \pm 17.52^{b}$ \\
\hline $2^{\circ} \mathrm{PCO}$ & 20 & $84.30 \pm 7.64^{c}$ & $120.15 \pm 15.93^{b}$ \\
\hline LSD & & 7.66 & 14.43 \\
\hline
\end{tabular}

- Legend as in Table (2)

\section{Conclusion}


This study concluded that is Prolactin, TSH and LH hormone are not associatedwith unexplained female infertility. The increase in $\mathrm{Cu}$ and iron may have an important etiological rolein the pathogenicity of unexplained female infertility.

\section{References}

1. Taylor A. Extent of the problem. $\mathrm{ABC}$ of subfertility. (2003);327:434-436.

2. Sadri-Ardekani H, Mizrak SC, van Daalen SK, Korver CM. Propagation of human spermatogonial stem cells in vitro. JAMA. (2009);302:2127-2134.

3. Slobodan V, Čukuranović R, Bjelaković MD. Possible therapeutic use of spermatogonial stem cells in the treatment of male infertility: a brief overview. Sci World J. 2012;8:374151.

4. Kakarla N BradshawK. Evaluation and Management of the Infertile. Glowm. (2008).

5. Centers for Disease Control and Prevention. Infertility FAQs. (2013).

6.Rowe PJ, Comhaire FH, Hargreave TB, Mahmoud AMA. WHOmanual for the standardized investigation, diagnosis and managementof the infertile male. Cambridge:Cambridge University Press; (2000).

7. Glenn L. Sandro C. Agarwal A. Unexplained Infertility. Springer Sci Media, LLC. (2015);14:2140-2149.

8. Collins JA, Burrows EA Harrild K,Mollison J, Wordsworth S, Tay C,Harrold A. The prognosis for live birth among untreated infertile couples. Fertil Steril. (1995);64:22-28.

9. Bhattacharya S, Harrild $\mathrm{K}$, Mollison J, Wordsworth S, Tay C, Harrold A. Clomifene citrate or unstimulated intrauterine insemination compared with expectant management for unexplained infertility: pragmatic randomised controlled trial. BMJ. (2008);337:716.

10. Dumesic DA, Oberfield SE, Stener-Victorin E, Marshall JC, Laven JS LR. Scientific statement on the diagnostic criteria, epidemiology, pathophysiology, and molecular genetics of polycystic ovary syndrome. Endocr Rev. (2015);36:487-525.

11. McCartney CR,Marshall.MJ. Clinical practice. Polycystic ovary syndrome. $N$ Engl $J \quad M e d$. (2016);375:54-64.

12. Anderson SA, Barry JA,HardimanPJ. Risk of coronary heart disease and risk of stroke in women with polycystic ovary syndrome: a systematic review and meta-analysis. Int J Cardiol. (2014);176:486-487.

13. Azziz R, Carmina E, Dewailly D, Diamanti-Kandarakis E, EscobarMorreale HF, Futterweit W, Janssen OE, Legro RS, Norman RJ, Taylor AE WS. Task Force on the Phenotype of the Polycystic Ovary Syndrome of The Androgen Excess and PCOS Society. The Androgen Excess and PCOS Society criteria for the polycystic ovary syndrome: the complete task force report. Fertil Steril. 
2009;91:456-488.

14. Uvarova EV,KhaschenkoKE. Polycystic ovarian syndrome according to modern pathogenesis data. Reprodukt Zdorov'e Detei Podrost Russ. (2013);5:54-60.

15. Wakim AN, Polizotto SL,BurholtDR. Influence of Thyroxine on Human Granulosa Cell Steroidogenesis in vitro. Wakim $A N$, Polizotto SL, Burholt DR. (1995);12:274-277.

16. Veeresh T, Moulali D,SarmaD. A Study on Serum FSH, LH and Prolactin Levels in Women with Thyroid Disorders. Int J Sci Res Publ. (2015);5:250-4.

17. Poppe K, Velkeniers B,Glinoer D. Thyroid Disease and Female Reproduction. ClinEndocrinol. (2007);309-21:309-321.

18. Zollner U, Lanig K, Steck T,Dietl J. Assessment of Endocrine Status in Patients Undergoing In- Vitro Fertilization Treatment. Is It Necessary? Arch GynecolObstet. 2001;265:16-20.

19. Mishra R, BavejaR, Gupta V. Prolactin Levels in Infertility with Menstrual Irregularities. $J$ Obs Gyynecol India. (2002);52:40-43.

20. Bouchard, P., Lagoguey, M., Brailly, S., Schaison G. Gonadotropinreleasing hormone pulsatile administration restores luteinizing hormone pulsatility and normal testosterone levels in males with hyperprolactinemia. $J$ Clin Endocrinol Metab. (1985);60:258-262.

21. Zinaman, M.J., Cartledge, T., Tomai, T., Tippett, P., Merriam GR. Pulsatile GnRH stimulates normal cyclic ovarian function in amenorrheic lactating postpartum women. $J$ Clin Endocrinol Metab. (1995);80:20882093.

22. Palm, I.F., van der Beek, E.M., Swarts, H.J., Van der Vilet, J., Wiegant, V.M., Buijs, R.M., Kalsbeek A. Control of the estradiol-induced prolactin surge by the suprachiasmatic nucleus.

Endocrinology.

(2001);142:2296-2302.

23. Fritz MA, Speroff L editors. Clinical gynecologic endocrinology and infertility. 8th ed Philadelphia Lippincott Williams Wilkins. (2011):501-18.

24. Pasha, Q., Malik, S. A., Iqbal, J., Shabeen, N., Shah MH. Screening of trace metals in the plasma of breast cancer patients in comparison with a healthy population. Hum Ecol Risk Assess. 2009;12:1016-1032.

25. Fraga CG. Relavance, essentiality and toxicity of trace elements in human health. Mol Asp Med. (2005);26:235-244.

26. Boffetta P. Carcinogenicity of trace elements with reference to evaluations made by the International Agency for Research on Cancer. Scand J Work Env Heal. (1993);1:67-70.

27. Pantopoulos K, Porwal SK,Tartakoff A. Mechanisms of mammalian iron homeostasis. Biochemistry. (2012);51:5705-24.

28. Kodama, H., Fujisawa C. Copper metabolism and inherited copper transport disorders: molecular mechanisms, screening and treatment. Metallomics. (2009);1:42-52.

29. Robertson J. D. Determination of Trace elements Levels in Human Plasma and Radiated Mice Tongue by Inductively Coupled Plasma-Mass 
Spectrometry (ICP-MS). Missouri Univ. (2012).

30. Beyazit F., Yilmaz N., Balci O. AM. Evaluation of Oxidative Stress in Women with Polycystic Ovarian Syndrome as Represented by Serum Ischemia Modified Albumin and Its Correlation with Testosterone and Insulin Resistance. Intern Med. (2016);55:2359-2364.

31. Verit F.F., Zeyrek F. F. , Zebitay A. G. Cardiovascular risk may be increased in women with unexplained infertility. Clin Exp Reprod Med. (2017);44:28-32.

32. George K. R. and Malini N. A. The Prevalence and Etiology of Polycystic Ovarian SyndromE (PCOS) as a Cause of Female Infertility in Central Travancore. An Int $Q$ J life Sci. (2014);9:1-6.

33. Shah A. K, Sarin M, Karunanand B, Mohapatra SC. Association of Hormonal status with Anthropometric \& Biochemical Parameters in women with Polycystic Ovarian Syndrome. Community Heal Manag January. (2017);4:30-34.

34. Diamond MP, Legro RS, Coutifaris C, Alvero R, Robinson RD, Casson PA, Christman GM, Huang H, Hansen KR, Baker V, Usadi R, Seungdamrong A, Bates GW, Rosen RM, Schlaff W, Haisenleder D, Krawetz SA, Barnhart K, Trussell JC, Santoro N, Eisenberg E, Zhang H. Sexual Function in Infertile Women with Polycystic Ovary Syndrome and Unexplained Infertility. Am J Obstet Gynecol. (2017);217:191.e1-191.e19.

35. Spandana J. C. ShettyP.K. A study on the clinical, biochemical and hormonal profile of polycystic ovary syndrome patients attending tertiary care hospital. Int J Reprod Contracept Obs Gynecol. (2017);6:1986.

36. Mohammed S., Awooda H. A., Rayis D. A., Hamdan H. Z., Adam I. LMF. Thyroid function/antibodies in sudanese women with polycystic ovarian disease. Obs Gynecol Sci. (2016);60:187-192.

37. Kumar AN, Naidu JN, Stayanarayana U. Past, present and future of insulin gene and its related genes in relation to polycystic ovary syndrome. J Mol Genet Med. (2014);8:107.

38. Poppe K,Velkeniers B. Thyroid disorders in infertile women. Ann Endocrinol.( 2003);64:45-50.

39. Frey KA,Patel KS. Initial evaluation and management of infertility by the primary care physicians. Mayo Clin Proc. (2004);79:1439-1443.

40. Valvekar U., Lakshmi S,KumarAN. Hypothyroidism and hyperprolactinemia showed positive correlation in women with primary and secondary infertility. Int $J$ Reprod.(2016);5:2079-2083.

41. Sultana A,NadirS. Pituitary gonadotropic hormones in women with oligo/amenorrhea. J Ayub Med Coll Abbottabad. J Ayub Med Coll Abbottabad. (2008);20:62-65.

42. Najem F, Elmehdawi R,Swalem A. Clinical and Biochemical Characteristics of Polycystic Ovary Syndrome in Benghazi- Libya; A Retrospective study. Libyan J Med. (2008);3:71-74.

43. Alwais A. A., Hamad A.R. Obiadat M. and Al-Al-Daghistani H. I. Study The Relationship Between Trace 
Elements and Hormones Among Jordanian Infertile Women. ejbps. (2016);3:589-598.

44. Li M. , Tang Y., Li C., Huang Q., Le D. H i Y. Serum macroelement and microelement concentrations in patients with polycystic ovary syndrome. Biol Trace Elem Res. (2016);176:73-80.

45. Rashid B. H, Shams S, Shariat M, Jaliseh H. K, Mohebi M, Haghollahi F. Evaluation of serum hepcidin and iron levels in patients with PCOS. Ital Soc Endocrinol. (2017);40:779-784.

46. Mishra A,TiwariA. Iron overload in Beta thalassaemia major and intermedia patients. Maedica (Buchar). (2013);8:328-332.

47. Singer S, Vichinsky E, Gildengorin G, van Disseldorp J, Rosen M CM. Reproductive capacity in iron overloaded women with thalassemia major. Blood. (2011);118:2878-2881.

48. Taghavi M Fatemi $\mathrm{S}$, AyatollahiH. Evaluation of body iron stores in non- Overweight women with polycystic ovarian syndrome and its correlation with Insulin resistance. Iran J Endocrinol Metab. (2009);10:600603.

49. AL-Saraf M. K. AL-Asadi A. Faris A.H. Copper and Zinc status in women with unexplained Infertility. AJPS. (2005);2:72-75.

50. Bawa R. TyagiS. Correlation of microelements like plasma copper and zinc concentrations with female infertility. Int J Reprod Contracept Obs Gynecol. (2017);6:2351-2353.

51. Muyan Li., TangY., Lin C.,
Huang Q., Lei D. HY. Serum Macroelement and Microelement Concentrations in Patients with Polycystic Ovary Syndrome: a CrossSectional Study. Springer Sci Media New York. (2016);176:73-80.

52. Kurdoglu Z, Kurdoglu M, Demir H. Serum trace elements and heavymetals in polycystic ovary syndrome. HumExp Toxicol. (2012);31:452-456.

53. David L. Watts D. The Nutritional Relationships of Copper. $J$ Orthomol Med. (1989);4:99-108.

54. Watts D,David L. Trace Elements and Other Essential Nutrients. 4th Writ B-L-O-C-K Ed USA. (2003).

55. Celik C, Bastu, Bastu E, Abali $\mathrm{R}$. The relationship between copper, homocysteine and early vascular disease in lean women with polycystic ovary syndrome. $J$ Gynecol Endocrinol.( 2013);29:488-491.

56. Chen TS, Chen YT, Liu $\mathrm{CH}$, Sun CC. Effect of chromium supplementation on element distribution in a mouse model of polycystic ovary syndrome. Biol Trace Elem Res. (2015);168:472-480.

57. Chasapis CT, Loutsidou AC, Spiliopoulou CA. Zinc and human health. Arch Toxicol. (2012);86:521534.

58. Chakraborty P,Ghosh S, Goswami SK, Kabir SN, Chakravarty B, Jana K. Altered trace mineralmilieu might play an aetiological role in the pathogenesis of polycystic ovary syndrome. Biol Trace Elem Res. (2013);152:9-15. 


\title{
تقدير الهرمونات والعناصر الندرة لدى النساء المصابات بالعقم غير المفسر
}

\author{
أ. د. رائد معلك حنون الصالح \\ م م م. خنساء عودة حسين \\ أ. د.ساهر عبد الرضا علي
}

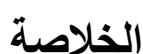

تهدف هذه الدراسة إلى تقييم هرمونالحليب (PRL)، هرمون تحفيز الغدة الدرفية (TSH)، هرمون التبيض

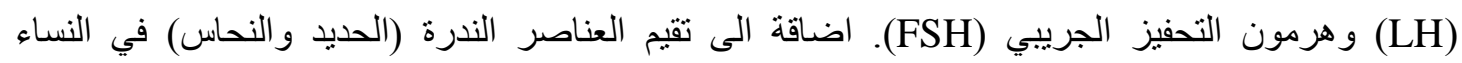

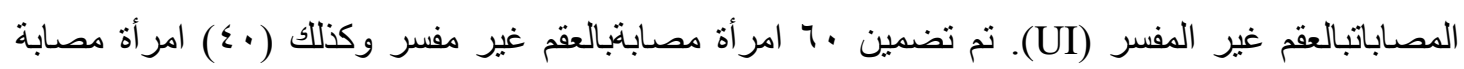

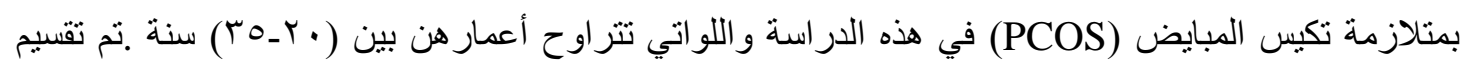
النساء العقيمات وفقا لنوع العقم الى مجموعة عقم اولي و مجموعة عقم ثانوي ( PCO , 2PCO

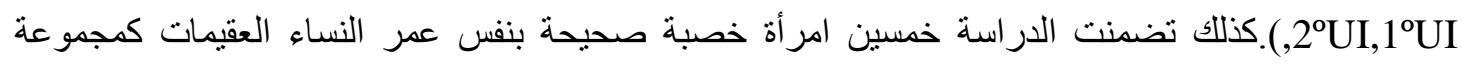
سيطرة .بينت النتائج وجود زيادة معنوية في مستوى الهرمونات,PRL ) TSH, (LH في مجموعتي النساء اللواتي يعانين من عقم (PCOS) مقارنة بمجموعةالسيطرة ومجموعني النساء اللواتي يعانين من العقم غير

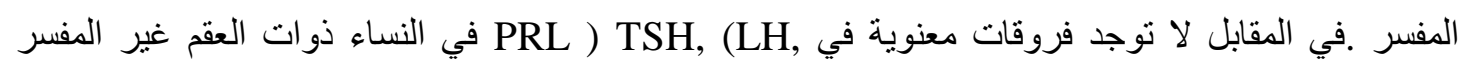


بالمقارنة مع مجموعة السيطرة ـ كما بينت النتائج ان هناك زيادة معنوية في مستويات الحديد و النحاس في مجموعتي العقم غير المفسر بالمقارنة مع مجموعة السيطرة و النساء ذوات العقم المفسر .وخلصت هذه هذه الدراسة إلى أن هرمونات PRL,TSH, LH, FSH ) ( لا تشترك باحداث مرض العقم غير المفسر لاى النساء . الزيادة في مستويات الحديدو النحاس قد يكون لها دور مسبب مهم في احداث مرض العقم غير المفسر لدى النساء. 